\title{
Stress and reproduction in farm animals
}

\author{
H. Dobson and R. F, Smith \\ Department of Veterinary Clinical Science and Animal Husbandry, University of Liverpool. \\ Leahurst, Neston, South Wirral, L64 7TE, UK
}

\begin{abstract}
Transport of post-partum cows or sheep before an oestradiol-induced LH surge delayed gonadotrophin secretion possibly by affecting hypothalamic activity but not via an opioid mediated mechanism as the effect could not be reversed by naloxone. In addition, reduced LH responses to $\mathrm{GnRH}$ were observed in cattle during transport. In sheep, adrenocorticotrophic hormone (ACTH) also diminished the $\mathrm{LH}$ response to $\mathrm{GnRH}$, but only when $\mathrm{GnRH}$ was administered $3 \mathrm{~h}$ after $\mathrm{ACTH}$, not after $0.5 \mathrm{~h}$. This finding suggests that very early suppression of $\mathrm{LH}$ secretion by stressors is not mediated by ACTH action at the pituitary but that immediate activation of the sympathetic nervous system may be involved. In ewes during the breeding season, repeated exposure to $\mathrm{GnRH}$ at intervals of $2 \mathrm{~h}$ during transport resulted in lower LH responses to the second and third injections. When anoestrous ewes were treated with oestradiol and $\mathrm{GnRH}$ while being restrained and isolated, the onset of the LH surge was delayed. The effects of hypothalamuspituitary-adrenal hyperactivity on LH release may involve suppression of GnRH receptor activity, a reduction in releasable $\mathrm{LH}$, or both factors. Studies in vitro with perifused ovine pituitaries showed that $\mathrm{ACTH}$ or corticotrophin releasing hormone markedly suppressed LH secretion in response to the second of two exposures to $\mathrm{GnRH}$. This occurred with pituitaries obtained from anoestrous ewes irrespective of prior treatment with oestradiol, suggesting that compounds from the hypothalamus-pituitary-adrenal do not exert effects on the oestradiol-sensitizing mechanisms on the pituitary. In conclusion, stressors affect reproductive function via actions at the hypothalamus as well as impairing pituitary LH release induced by $\mathrm{GnRH}$.
\end{abstract}

\section{Introduction}

There is little doubt that stress has a deleterious effect on reproductive efficiency in farm animals; however, much of the evidence is at best circumstantial, at worst in the realms of old wives tales. Clearly, attempts to establish the mechanisms involved in the influence of increased hypothalamuspituitary-adrenal activity on reproductive function must be accompanied by definitive proof of the effect of stressors on specific reproductive parameters.

In dairy cows, the chronic stressors of periparturient diseases or lameness increase the interval from calving to conception and the number of inseminations required per conception (Borsberry and Dobson, 1989: Collick et al., 1989). Frequent wetting of sheep during oestrus or transport of cows during a superovulation programme result in a significant decrease in ovulation rate (Doney et al., 1976; Edwards et al., 1987), and intermittent foot-shocks or administration of Escherichia coli toxin are associated with the presence of cystic follicles (Przekop et al., 1984; Peter et al., 1990).

Administration of adrenocorticotrophic hormone (ACTH) during the follicular phase of the oestrous cycle in heifers results in the formation of persistent follicles (cysts) and emergence of other follicles is suppressed for up to 10 to 15 days (Fig. $I_{;}$A.Y. Ribadu, R.F. Smith and H. Dobson, unpublished). 


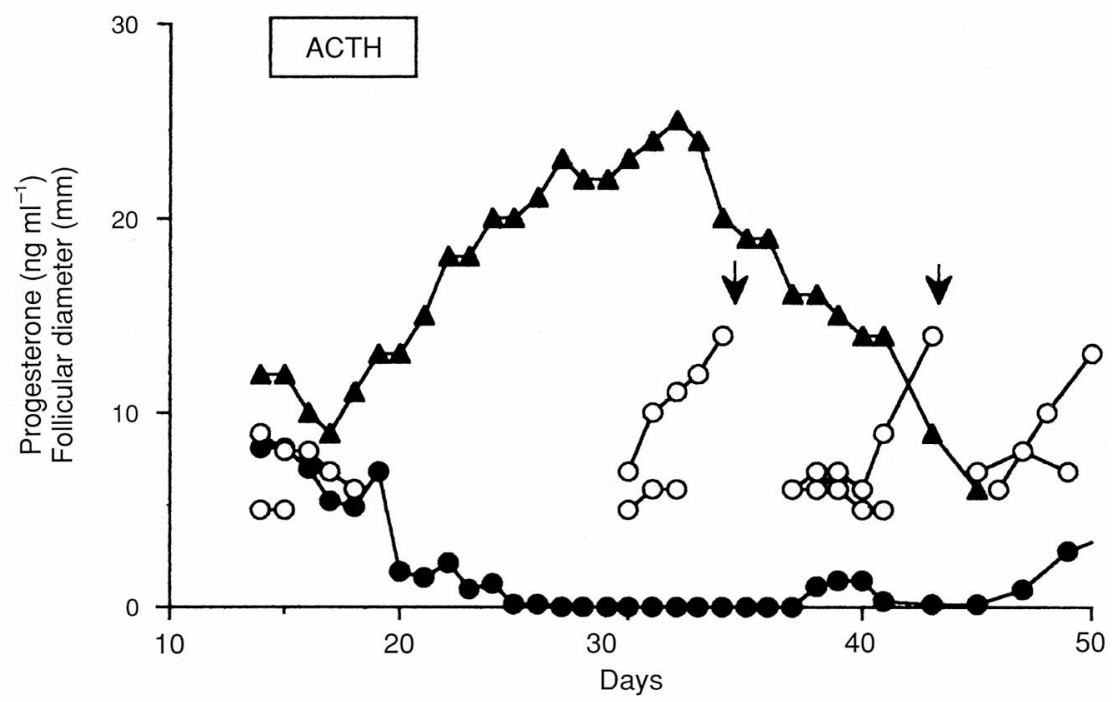

Fig. 1. Peripheral concentration of progesterone (-) and the diameter of a persistent follicle $(\boldsymbol{\Lambda})$ and all other ovarian follicles $>5 \mathrm{~mm}(O)$ as determined by ultrasound in a representative heifer treated on day 15 of the oestrous cycle with 100 iu ACTH every $12 \mathrm{~h}$ for 7 days as shown by the horizontal bar. The arrows denote ovulation of the appropriate follicles.

There is no detailed information available concerning the effect of stressors on fertility per se in male ruminants.

\section{Responses to Stressors}

Types of stressors include physical stressors, e.g. transport or mechanical injury, psychological stressors, e.g. isolation in sheep or the approach of strangers, and physiological stressors, e.g. insulin-induced hypoglycaemia or changes in blood pressure. Different stressors evoke different activation mechanisms within the hypothalamus-pituitary-adrenal axis. For example, the ratio of the principal corticotrophin releasing factors, corticotrophin releasing hormone (CRH) to arginine vasopressin (AVP), in hypophysial-portal blood, and that of ACTH to $\beta$-endorphin in peripheral blood differ after exposure to a barking dog or insulin-induced hypoglycaemia (Engler et al., 1988, 1989). Nevertheless, all stimuli result in increased corticosteroid secretion from the adrenal glands. The significance of the different ratios of the hypothalamus-pituitary-adrenal hormones is not clear; however, investigations into mechanisms by which different stressors influence the hypothalamus-pituitary-gonad axis need to take these different ratios into account.

In addition, it is known that there are negative feedback mechanisms that are necessary to protect the animal against overactivation of the hypothalamus-pituitary-adrenal axis, and such negative feedback mechanisms vary between stressors (Munck et al., 1984; Canny et al., 1989, 1990). For example, within $45 \mathrm{~min}$, peripheral cortisol concentrations begin to decline, reaching the baseline value by the end of $6 \mathrm{~h}$ restraint and isolation in sheep, in spite of continued behavioural signs of agitation (C. Guy, R. F. Smith and H. Dobson, unpublished), whereas values do not decrease to baseline values during first transportation (Smart et al., 1994a). It may be differences in negative feedback within the hypothalamuspituitary-adrenal axis that influence reproductive hormone secretion rather than the initial activation of the hypothalamus-pituitary-adrenal axis. This aspect has received no attention in the literature.

Furthermore, it must be remembered that habituation to stressors does occur, an extremely important fact in experimental design. For example, Rasmussen and Malven (1983) showed a complete reversal of the suppressive effects on LH frequency and amplitude by the third day of exposure to 
restraint on three consecutive days. However, when sheep were isolated at intervals of 3 days, hypothalamus-pituitary-adrenal responses were similar (Niezgoda et al., 1987). Mechanisms associated with habituation, such as the downregulation of CRH receptors (Canny et al., 1990), may be involved in differential effects of chronic or acute stressors on reproductive hormone secretion. This aspect has also received no attention in ruminants.

A word of caution must be given when considering stress and reproduction studies in rats. First, the unstressed rat depends on adrenal progesterone to facilitate the onset of the preovulatory LH surge at an exact time on the day of oestrus (Brann and Mahesh, 1991). Second, with such a short 4 or 5 day oestrous cycle, very precisely timed events may be overlooked or masked when many animals have to be used to obtain sufficient volumes of samples to measure certain hormones with the relatively insensitive assay systems currently available. Third, anaesthesia has been used in many experiments when obtaining appropriate samples for hormone measurement from specific regions of the hypothalamus or from hypophysial portal vessels, and this process interferes with spontaneous responses to applied stressors.

\section{Hypothesis to Explain the Influence of Stress on Reproduction}

On the basis of our own work and that of others, our hypothesis is that there are two main mechanisms by which activation of the hypothalamus-pituitary-adrenal axis reduces the efficiency of the hypothalamus-pituitary-gonad axis. The first mechanism involves interference with correctly timed $\mathrm{GnRH}$ secretion controlled by neurotransmitters, and the other is the deleterious influence of hypothalamus-pituitary-adrenal hormones (especially ACTH) on the action of GnRH at the pituitary.

Most evidence suggests that, although stressors can cause fetal losses in mid-to-late pregnancy, the highest percentage of stress-induced reproductive losses occurs as a result of interference with correct hypothalamus-pituitary function; early embryonic losses result from inappropriate exposure of the ovum to gonadotrophins within the follicle (Staigmiller and Moor, 1984).

The following review is not intended to include every publication on stressors and reproduction in farm animals, but rather to present evidence for a coherent hypothesis for further testing. For brevity we have omitted some observations but we are not aware of any of significance that would make the hypothesis untenable. References to heat as a stressor have been excluded to avoid confusion with the consequent effects of altered rates of metabolism rather than activation of the hypothalamus-pituitaryadrenals per se. There is little evidence in domestic ruminants so, when appropriate, reference is made to primates and rats.

\section{Effects of Common Stressors on Reproduction}

\section{Transport}

Transport delays the onset of the LH surge in both cows and sheep (Nanda et al., 1989; Smart et al., 1994b; Table 1). This stressor must be initiated within hours of the onset of the LH surge (Fig. 2), and the delay is more marked if transport is imposed early in the postpartum period rather than in the middle of the breeding season (Nanda et al., 1990b; Dobson and Nanda, 1992; Table 1). In control animals, morphine acts at the hypothalamus to block the LH surge in cattle, and the effects are reversed by the opioid antagonist, naloxone (Nanda et al., 1990a). However, stressor suppression of LH secretion in cows and sheep could not be reversed by prior treatment with naloxone, contrary to similar experiments in rats (Malven, 1987; Nanda et al., 1989; Table 1). At the pituitary, the response to GnRH (to give LH concentrations similar to the spontaneous pulse amplitude; Rahe et al., 1980) was reduced within $15 \mathrm{~min}$ of the start of transport in cattle (Fig. 3; Dobson, 1987). Furthermore, in ewes during the breeding season, repeated exposure to $\mathrm{GnRH}$ at intervals of $2 \mathrm{~h}$ during transport resulted in markedly lower $\mathrm{LH}$ responses to the second and third GnRH injections (Fig. 4; J. Phogat, R. F. Smith and H. Dobson, unpublished). 
Table 1. Time ( \pm SEM) to the onset of the LH surge after $50 \mu \mathrm{g}$ oestradiol benzoate (injected at time 0 ) in ewes of different reproductive and hypothalamus-pituitary-adrenal status, with or without additional injections of $500 \mathrm{ng} \mathrm{GnRH}$

\begin{tabular}{|c|c|c|}
\hline Reproductive status & $\begin{array}{l}\text { Time } \\
\text { (h) }\end{array}$ & $\begin{array}{l}\text { Number } \\
\text { of ewes }\end{array}$ \\
\hline \multicolumn{3}{|l|}{ Day 14 postpartum } \\
\hline Oestradiol alone & $14.7 \pm 0.5^{*}$ & 8 \\
\hline Transport from $+10 \mathrm{~h}$ to $+14 \mathrm{~h}$ & $17.5 \pm 0.8$ & 5 \\
\hline Transport plus naloxone $\left(3 \times 1 \mathrm{mg} \mathrm{kg}^{-1}(2 \mathrm{~h})^{-1}\right.$ from $\left.+10 \mathrm{~h}\right)$ & $18.0 \pm 0.4$ & 8 \\
\hline $0.8 \mathrm{mg} \mathrm{ACTH}$ at $\mathrm{O} \mathrm{h}$ and $+10 \mathrm{~h}$ & $18.0 \pm 0.7$ & 8 \\
\hline \multicolumn{3}{|l|}{ Mid-anoestrus } \\
\hline $\mathrm{GnRH}$ at $+10.5 \mathrm{~h}$ and $+13 \mathrm{~h}$ & $15.1 \pm 1.7$ & 5 \\
\hline Restraint and isolation from $+10 \mathrm{~h}$ to $+16 \mathrm{~h}$ & $16.7 \pm 1.8$ & 5 \\
\hline Restraint and isolation plus $\mathrm{GnRH}$ at $+10.5 \mathrm{~h}$ and $+13 \mathrm{~h}$ & $18.9 \pm 0.9 *$ & 5 \\
\hline \multicolumn{3}{|l|}{ Cyclic, $24 \mathrm{~h}$ after prostaglandin synchronization } \\
\hline Oestradiol alone & $20.5 \pm 5.3$ & 7 \\
\hline Oestradiol plus $3 \times \mathrm{GnRH}$ (at $+8 \mathrm{~h},+10 \mathrm{~h}$ and $+12 \mathrm{~h}$ ) & $24.3 \pm 5.9$ & 8 \\
\hline Oestradiol plus $3 \times \mathrm{GnRH}$ plus transport from $+7.5 \mathrm{~h}$ to $+15 \mathrm{~h}$ & $23.8 \pm 3.7$ & 8 \\
\hline Oestradiol plus $0.8 \mathrm{mg} \mathrm{ACTH}$ at $\mathrm{O} \mathrm{h}$ and $+7.5 \mathrm{~h}$ plus $3 \times \mathrm{GnRH}$ & 28 and $18 * *$ & 6 \\
\hline
\end{tabular}

Data from Smart et al. (1994) and C. Guy, J. B. Phogat, R. F. Smith and H. Dobson (unpublished).

*Different from other means for ewes of the same reproductive status $(P<0.05)$.

**Four of the ewes in this group did not have an LH surge.

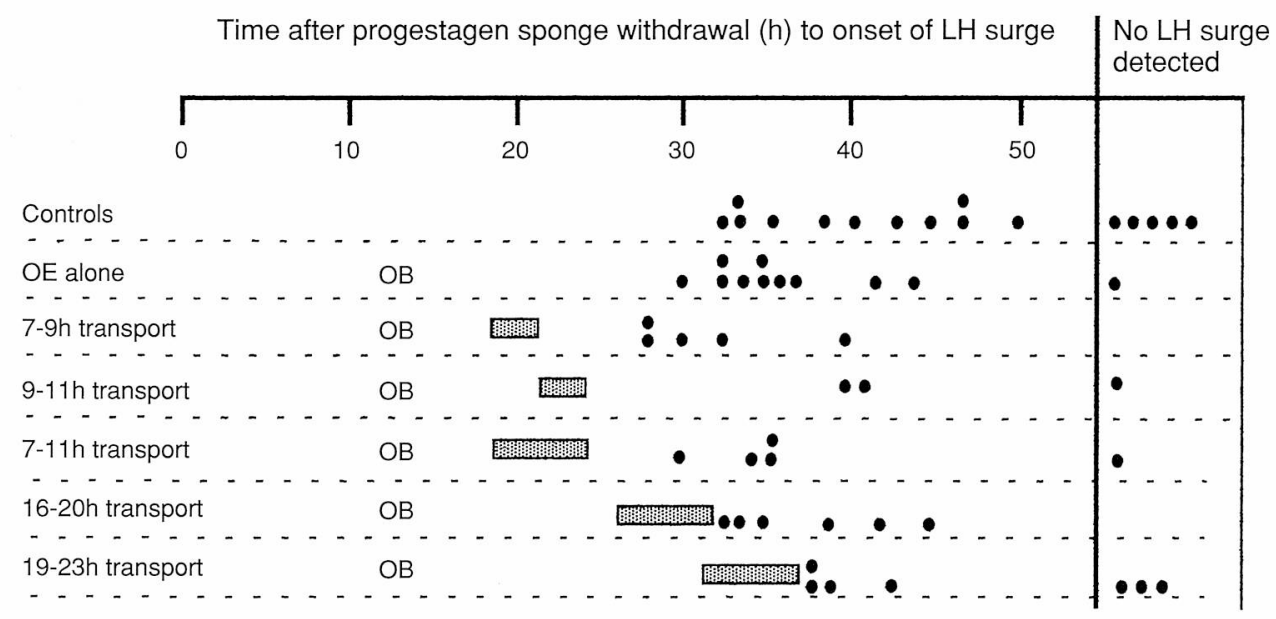

Fig. 2. Time of onset (•) of the LH surge after progestagen sponge withdrawal in individual ewes in the breeding season that were treated with oestradiol benzoate $(50 \mu \mathrm{g})$ at times indicated by $\mathrm{OB}$, and subjected to 2 or $4 \mathrm{~h}$ transport as shown by the horizontal bar ( $\square$ ). Data from Dobson and Nanda (1992).

\section{Restraint}

Restraint, of varying severity and usually accompanied by isolation from other animals of the same species, has been used by several groups as a psychological stressor. The occurrence of spontaneous LH surges was prevented in two out of seven heifers restrained for $15 \mathrm{~min}$ twice a day for 3.5 days during the follicular phase (Stoebel and Moberg, 1982a). There was no delay in the onset of the LH surge when ewes were restrained after administration of oestradiol during anoestrus; however, if the ewes had 


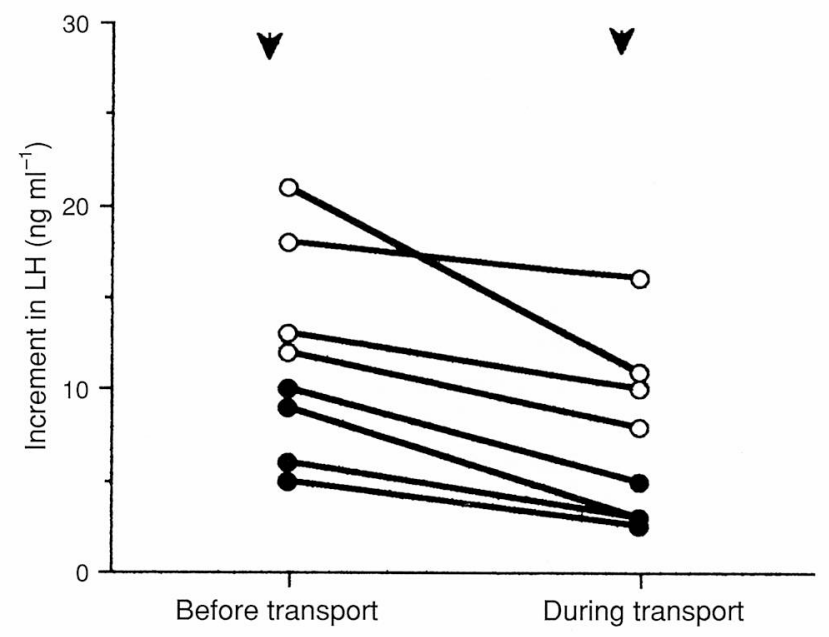

Fig. 3. Maximum increment in $\mathrm{LH}$ concentrations in individual cows treated with $20(0)$ or $40(\bigcirc) \mu \mathrm{g}$ GRH (arrows) either one day before or $15 \mathrm{~min}$ after the start of transport. Data from Dobson (1987).

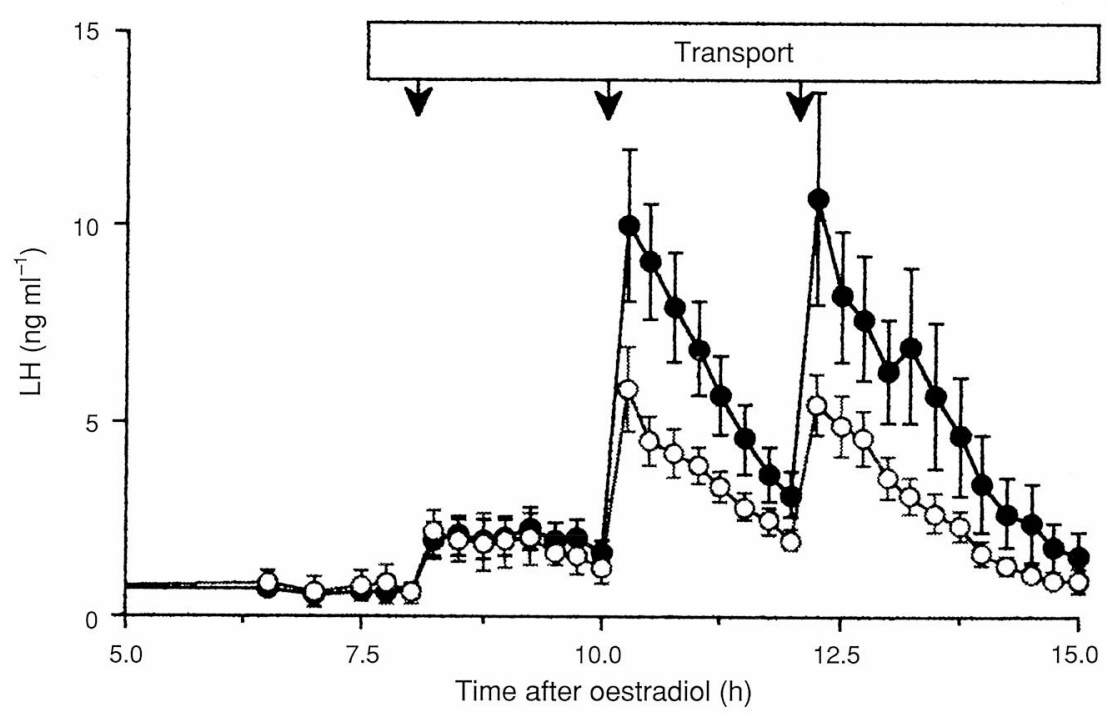

Fig. 4. Concentration of LH ( \pm SEM) in ewes in the breeding season treated with oestradiol benzoate $(50 \mu \mathrm{g}) 24 \mathrm{~h}$ after prostaglandin synchronization with $(O ; n=8)$ or without $n=8$ ) transport (duration indicated by the horizontal bar $\square$ ) and $500 \mathrm{ng} \mathrm{GnRH}$ administered at times shown by the arrows. In control ewes not given $\mathrm{GnRH}$, the concentration of LH did not exceed $1.5 \mathrm{ng} \mathrm{ml}^{-1}$.

already released LH in response to additional treatment with two $500 \mathrm{ng}$ doses of GnRH during restraint, the LH surge was delayed by $3 \mathrm{~h}$ (Table $\mathrm{I}$ ). In ewes and monkeys, restraint decreased the amplitude and frequency of LH secretion indicating effects at the hypothalamus (Rasmussen and Malven, 1983; Norman and Smith, 1992). There are similar observations in ovariectomized rats, and effects in this species were reversed by intracerebroventricular (i.c.v.) administration of a CRH antagonist (Rivier and Rivest, 1991). In an experiment with oestradiol-treated anoestrous ewes, we were unable to show a reduction in the $\mathrm{LH}$ response to $500 \mathrm{ng} \mathrm{GnRH}$ at 0.5 and $3.0 \mathrm{~h}$ after the start of restraint and isolation 
(C. Guy, R. F. Smith and H. Dobson, unpublished) but II out of 16 rams had a lowered response to one injection of $10 \mu \mathrm{g} \mathrm{GnRH}$ after 3-6 h restraint (Matteri et al., 1984).

\section{Foot-shocks}

Intermittent electrical foot-shocks for $9 \mathrm{~h}$ on each day after days 14-16 of the cycle resulted in the absence of a spontaneous preovulatory LH surge in two of ten ewes (Przekop et al., 1984). Such treatment for $20 \mathrm{~min}^{-1}$ for 3 consecutive days in anoestrus resulted in increased concentrations of $\mathrm{GnRH}$ in the median eminence and preoptic areas of the hypothalamus presumably as a result of inhibition of GnRH release (Przekop et al., 1988). In adult castrated male rats, intermittent foot-shocks decreased peripheral LH concentrations even after adrenalectomy; this effect was reversed by i.c.v. administration of a CRH antagonist (Rivier and Rivest, 1991).

\section{Hypoglycaemia}

Hypoglycaemia induced by acute administration of insulin caused a simultaneous decrease in $\mathrm{GnRH}$ and LH secretion in testosterone-treated rams (A. Caraty, personal communication). Similarly, insulin reduced the frequency and amplitude of pulsatile $\mathrm{LH}$ secretion in long-term ovariectomized ewes; the effect was reversed by prior and simultaneous glucose administration (substantiating a neuroglycopneic effect) as well as by naloxone treatment, the latter suggesting opioid mediation during this particular stressor (Clarke et al., 1990).

\section{Infection}

Infectious agents are often reputed to cause a reduction in reproductive efficiency in farm animals. Treatment of heifers with Escherichia coli toxin lowered the concentration of LH in the early follicular phase and inhibited the release of the preovulatory LH surge (Peter et al., 1990). There is considerable evidence from work in monkeys and rats that implicates interruption of GnRH secretion by neuronal components of the immune response, for example interleukin I, by CRH-mediated mechanisms (Ferin, 1993; Rivest and Rivier, 1993).

\section{Hormonal Mediators of the Stress Response}

\section{Cortisol}

In cattle, infusion of cortisol for $90 \mathrm{~h}$ during the follicular phase prevented the preovulatory LH surge in six of eight heifers (Stoebel and Moberg, 1982b; Li and Wagner, 1983a). However, basal LH concentration was not affected (Stoebel and Moberg, I982b), nor was the LH response to GnRH in vivo (cited by Moberg et al., 1981), although these latter observations have been disputed (Li and Wagner, 1983b; Dobson et al., 1987). In bulls, dexamethasone reduced LH and testosterone concentrations, and lowered the LH response to GnRH (Chantaraprateep and Thibier, 1979). Perifusion with medium containing cortisol in vitro did not affect GnRH secretion from bovine median eminence tissue (Katawe et al., 1993), or basal LH secretion from bovine pituitary cell cultures (Padmanabhan et al., 1983). Using a perifusion system, Katawe et al. (1993) could not demonstrate an acute effect of treatment with cortisol for $4 \mathrm{~h}$ on $\mathrm{LH}$ released by exposure to $8 \mathrm{nmol} \mathrm{GnRH} \mathrm{l}^{-1}$ for $20 \mathrm{~min}$; however, pituitary cells cultured for 5 days and incubated with cortisol for 6-24h secreted less $\mathrm{LH}$ after stimulation with $0.85 \mathrm{nmol}$ GnRH $1^{-1}$ (Li and Wagner, 1983b; Padmanabhan et al., 1983). Significantly, if the pituitary cells were already primed with $\mathrm{GnRH}$, the suppressive effects of cortisol were reversed (Padmanabhan et al., 1983).

In sheep, neither cortisol nor the synthetic glucocorticoid dexamethasone affected an oestradiolinduced LH surge in anoestrous ewes (Moberg et al., 1981; Phillips and Clarke, 1990), although tonic LH secretion was reduced by infusion of cortisol for $10 \mathrm{~h}$ in ewes ovariectomized for more than 2 months 


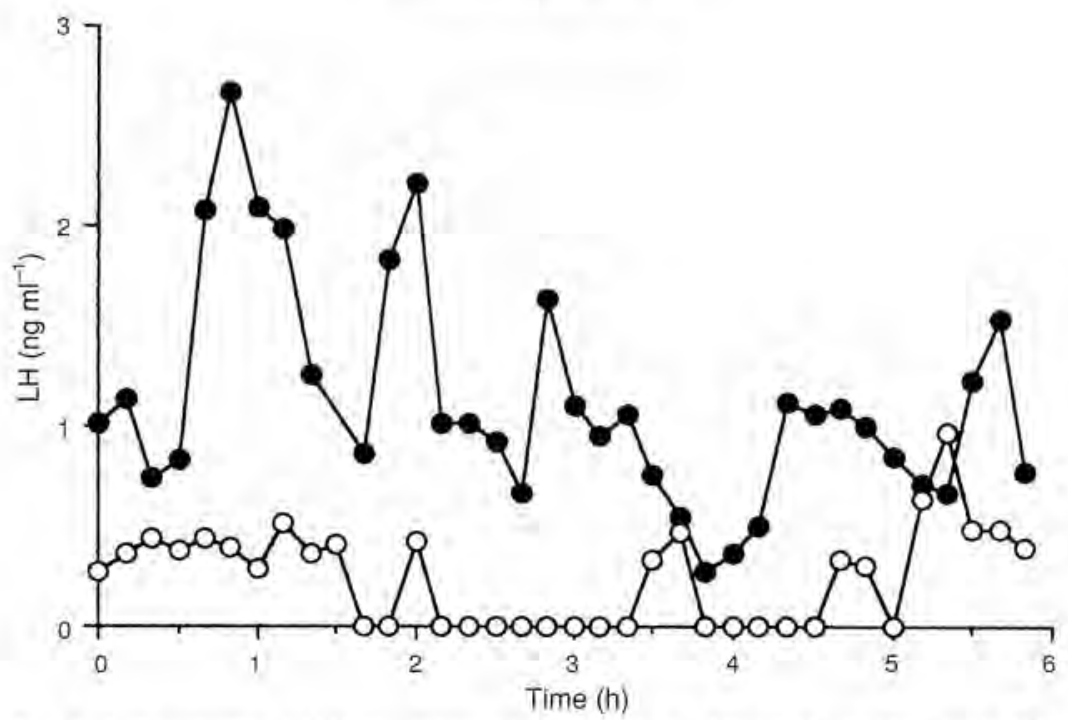

Fig. 5. Concentration of LH in a representative heifer on day 19 of a control cycle (-) and on day 19 of a cycle in which treatment with $1 \mathrm{mg}$ ACTH every $12 \mathrm{~h}$ for 7 days commenced on day $15(0)$.

(Porter et al., 1990). Long-acting dexamethasone did not affect the negative feedback effect of chronic oestradiol treatment in ovariectomized ewes (Phillips and Clarke, 1990). Treatment of intact or adrenalectomized rams with cortisol did not alter the LH response to the high dose of $100 \mu \mathrm{g} \mathrm{GnRH}$ (Fuquay and Moberg, 1983), nor did dexamethasone affect the LH response to $\mathrm{I} \mu \mathrm{g}$ GnRH given to ewes in anoestrus or in the breeding season (Phillips and Clarke, 1990). However, infusion of cortisol to long-term ovariectomized ewes reduced the LH response to $500 \mathrm{ng}$ GnRH (Porter et al, 1990). Much of the confusion about the effects of cortisol on GnRH-induced LH release in ruminants is probably due to dose-dependent effects of GnRH. In rats, large doses of dexamethasone affect GnRH-induced LH release in castrated male rats (Rivier and Rivest, 1991).

\section{Adrenocorticotrophic hormone}

In cows, administration of ACTH in spontaneous follicular phases inhibits the appearance of a spontaneous LH surge, but it has yet to be resolved whether this is a direct effect of ACTH on the hypothalamus-pituitary-gonad axis or an indirect effect via the stimulation of adrenal progesterone secretion (Liptrap and McNally, 1976; Stoebel and Moberg, 1982b; Li and Wagner, 1983b; Fig. 1). Baseline $\mathrm{LH}$ values were also suppressed by $\mathrm{ACTH}$ in the follicular phase as well as during the postpartum period (Dunlap et al., 1981; Stoebel and Moberg, 1982b; Li and Wagner, 1983b). More recent work has confirmed that the effect in the follicular phase is reflected in fewer LH pulses (Fig. 5; K. Noble, R. F. Smith and H. Dobson, unpublished) as in ovariectomized adrenalectomized rats (Rivier and Rivest, 1991), Infusion of ACTH for 5-9 days suppressed LH release in response to GnRH in vivo (Li and Wagner, 1983b), but LH basal secretion in vitro was not affected, nor was that stimulated by a single exposure to GnRH (Padmanabhan et al, 1983).

In ewes, either in anoestrus or early in the postpartum period, ACTH inhibited or delayed oestradiol-induced LH surges if administered immediately before the expected onset (Dobson et al., 1988; Table 1). The LH response to $\mathrm{GnRH}$ was suppressed in intact or adrenalectomized rams and intact anoestrous ewes, and the greatest effect was $3-6 \mathrm{~h}$ rather than $0.5 \mathrm{~h}$ after ACTH treatment (Fig. 6 ; Fuquay and Moberg, 1983; Matteri et al., 1984; Dobson et al, 1988; Mohamed et al., 1988). This delay of effect was in contrast to that seen during hypothalamus-pituitary-adrenal stimulation by transport 


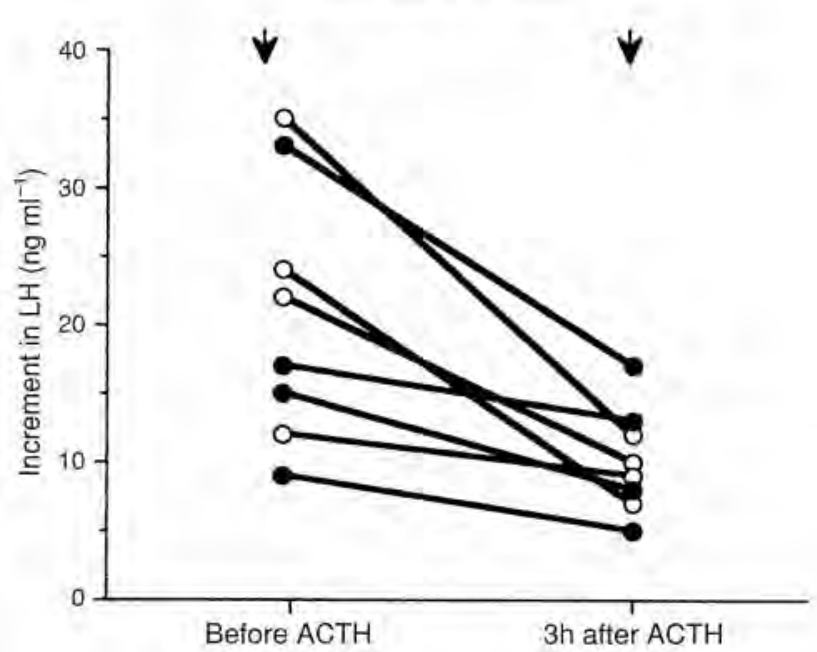

Fig. 6, Maximum increment in $\mathrm{LH}$ concentrations in individual anoestrous ewes treated with $500 \mathrm{ng} \mathrm{GnRH}$ (arrows) one week before and $3 \mathrm{~h}$ after $1 \mathrm{mg}(-)$ or $0.5 \mathrm{mg}(\mathrm{O}) \mathrm{ACTH}$ treatment. Data redrawn from Dobson et al. (1988).

(Dobson, 1987); the discrepancy might be due to immediate suppressive effects exerted by adrenaline secretion from the adrenal medulla (Parrott et al., 1994). Perifusion of either male or female pituitary fragments in vitro confirmed the suppressive effects of ACTH on GnRH-induced LH release and emphasized effects mediated by the self-priming nature of GnRH action (Matteri et al., 1986; Smart, 1994; Fig. 7). This effect was observed in all perifused pituitaries, irrespective of prior treatment with oestradiol in vivo (D. Smart, personal communication), suggesting that the effect might not be mediated by affecting oestradiol-sensitizing mechanisms at the pituitary.

\section{Corticotrophin releasing hormone and arginine vasopressin}

In sheep, the situation is confusing. Administration of $\mathrm{CRH}(10 \mu \mathrm{g})$ i.c.v. with or without simultaneous AVP $(10 \mu \mathrm{g})$ to ovariectomized ewes was reported to have no effect on peripheral $\mathrm{LH}$ profiles (Clarke et al, 1990), whereas similar doses of CRH i.c.v. increased LH pulse frequency presumably via the hypothalamus but this was not altered by prior i.c.v. treatment with naloxone (Naylor et al., 1990). In contrast, prior exposure of perifused pituitary tissue to CRH resulted in a suppression of $\mathrm{GnRH}$-induced LH release; however, this could have been mediated by release of ACTH in vitro (Fig. 7; Smart, 1994).

In monkeys, neither corticoid nor ACTH treatment affects LH secretion; however, peripheral administration of $\mathrm{CRH}$ to intact or ovariectomized monkeys inhibits LH pulse frequency, suggesting a hypothalamic site of action (Ferin, 1993) confirmed by CRH-induced inhibition of GnRH secretion from hypothalamic tissue in vitro (Williams et al., 1990).

In rats, there is evidence both in vivo and in vitro for a suppressive effect of $\mathrm{CRH}$ on GnRH (and hence $\mathrm{LH}$ ) secretion mediated at the hypothalamus by opioidergic and catecholaminergic pathways (Rivier and Rivest, 1991).

\section{Conclusion}

We were led to our hypothesis through a consideration of the widespread evidence, often contradictory both within and between species, concerning the influence of a variety of stressors or hypothalamus- 


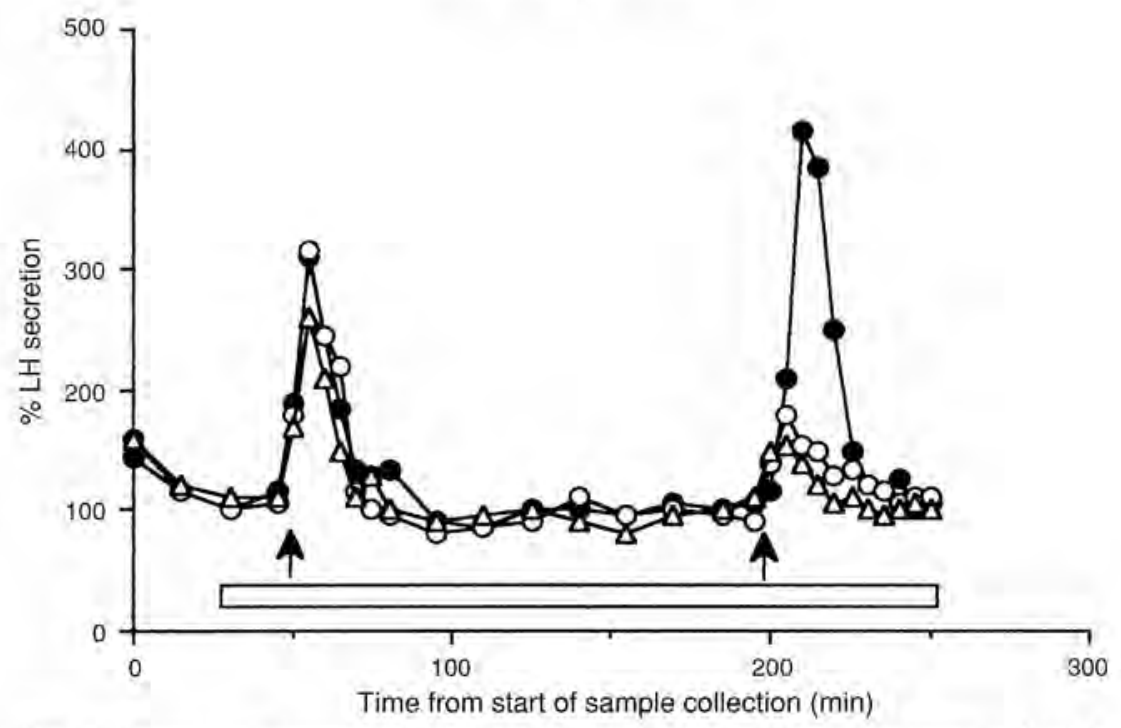

Fig. 7. Percentage increase in $\mathrm{LH}$ concentrations (in relation to pretreatment values) in ovine pituitary in vitro perifusion eluates after two $2 \mathrm{~min}$ exposures (arrows) to $10^{-9} \mathrm{~mol}$ GnRH $1^{-1}$ at intervals of $2.5 \mathrm{~h}$ in the absence of other additions to the medium (-) or in the presence of $10^{-7} \mathrm{~mol} \mathrm{ACTH} \mathrm{I}{ }^{-1}(O)$ or $2.5 \times 10^{-8} \mathrm{~mol} \mathrm{CRH} \mathrm{I}{ }^{-1}(\triangle)$ for duration indicated by the horizontal bar ( $\square$ ).

pituitary-adrenal hormones on hypothalamic-pituitary function. After reinterpretation of some of the data, we present a unified framework for further investigation.

In rats and monkeys, there is good evidence that, in situations of increased CRH synthesis and secretion, the release of GnRH is inhibited. Synapses between CRH and GnRH neurones have been identified in rats (MacLusky et al, 1988) and, although such neuronal links remain to be described in sheep and cattle, it is clear that the role of CRH via catecholaminergic and opioidergic mechanisms must be clarified in ruminants. The doses of exogenous CRH used so far in sheep may exert so strong a downregulation on $\mathrm{CRH}$ neurones that $\mathrm{GnRH}$ neurones are released from suppression and hence $\mathrm{LH}$ secretion is increased; alternatively, $\mathrm{CRH}$ may act as a neurotransmitter to release $\mathrm{GnRH}$ in this species.

Stressors or exposure to different components of the hypothalamus-pituitary-adrenal axis have a maximum suppressive effect on gonadotrophin secretion when the hypothalamus-pituitary-gonad axis is either under compromise, as in the early postpartum period (Alam and Dobson, 1987; Dobson and Alam, 1987), or in situations in which stimulation of the hypothalamus-pituitary is maximal, such as immediately before the LH surge or in the absence of steroid suppression, either in vitro or in gonadectomized animals. Components of the hypothalamus-pituitary-adrenal axis may inhibit GnRH self-priming by disrupting (i) GnRH receptor regeneration as self-priming involves increased numbers of GnRH receptors (Khalid et al., 1991), (ii) post-receptor signal transduction necessary for LH secretion (Clayton, 1989), or (iii) provision of sufficient LH in a releasable form (Hoff et al., 1977). Each of these aspects requires investigation,

Finally, it remains to be determined which site of action is of paramount importance, the hypothalamus or the pituitary.

The authors are grateful to C. Guy, A. S. Nanda, K. Noble, J. B. Phogat, A. Y. Ribadu and D. Smart for collaborative work and stimulating discussion. The technical support of H. Purcell, T. Roscoe, I. Smith, N. Jones and his farm staff is acknowledged, as well as provision of assay reagents from the National Hormone and Pituitary Program. Work undertaken by the authors, described in this review, was supported by the AFRC (UK), Wellcome Trust, Association of Commonwealth Universities, Whitley Animal Protection Trust and Journals of Reproduction and Fertility, Ltd. 


\section{References}

Alam MGS and Dobson H (1987) Pituitary responses to a challenge test of GnRH and oestradiol benzoate in postpartum and regularly cyclic dairy cows Animal Reproduction Science 14 I-9

Borsberry S and Dobson H (1989) Periparturient diseases and their effect on reproductive performance in five dairy herds Veterinary Record 124 217-219

Brann DW and Mahesh (I991) Regulation of gonadotropin secretion by steroid hormones Frontiers in Neuroendocrinol ogy 12 165-207

Canny BJ, Funder JW and Clarke IJ (1989) Glucocorticoids regulate ovine hypophysial portal levels of corticotropinreleasing factor and arginine vasopressin in a stress-specific manner Endocrinology 125 2532-2539

Canny BJ, Clarke IJ and Funder JW (1990) Adrenocorticotropin responses to endogenous and exogenous secretagogues in the sheep: specificity of glucocorticoid action Neuroendocrinology 51 181-189

Chantaraprateep P and Thibier M (1979) Effects of dexamethasone on the responses of luteinising hormone and testosterone to two injections of luteinising hormone releasing hormone in young postpubertal bulls Journal of Endocrinology 77 389-395

Clarke IJ, Horton RJE and Doughton BW (1990) Investigation of the mechanism by which insulin-induced hypoglycemia decreases luteinising hormone secretion in ovariectomized ewes Endocrinology 127 1470-1476

Clayton RN (1989) Gonadotrophin-releasing hormone: its actions and receptors Journal of Endocrinology 120 11-19

Collick DW, Ward WR and Dobson H (1989) Association between types of lameness and fertility Veterinary Record 125 103-106

Dobson H (1987) Effect of transport stress on luteinising hormone released by GnRH in dairy cows Acta Endocrinologica 115 63-66

Dobson H and Alam MGS (1987) Preliminary investigations into the endocrine systems of subfertile cattle: location of a common lesion (rate-limiting step) Journal of Endocrinology 113 167-171

Dobson H and Nanda AS (1992) Effect of transport on LH surge release induced by oestradiol in ewes Journal of Reproduction and Fertility Supplement 43 307-308

Dobson H, Alam MGS and Kanchev LN (1987) Effect of betamethasone treatment on luteal lifespan and the LH response to GnRH in dairy cows Journal of Reproduction and Fertility 80 25-30

Dobson H, Essawy SA and Alam MGS (1988) Suppression of LH response to gonadotrophin-releasing hormone or oestradiol by $\mathrm{ACTH}(1-24)$ treatment in anoestrous ewes Journal of Endocrinology 118 193-197

Doney JM, Gunn RG, Smith WF and Carr WR (1976) Effects of pre-mating environmental stress, $\mathrm{ACTH}$, cortisone acetate or metyrapone on oestrus and ovulation in sheep Journal of Agricultural Science 87 127-132

Dunlap SE, Kiser TE, Cox NM, Thompson FN, Rampacek GB, Benyshek LL and Kraeling RR (1981) Cortisol and luteinising hormone after adrenocorticotrophic hormone administration to postpartum beef cows Journal of Animal Science 52 587-593
Edwards LM, Rahe CH, Griffin JL, Wolfe DF, Marple DN, Cummins KA and Pitchett JF (1987) Effect of transportation stress on ovarian function in superovulated Hereford heifers Theriogenology 28 291-302

Engler D, Pham T, Fullerton MJ, Funder JW and Clarke IJ (1988) Studies of the regulation of the hypothalamic-pituitaryadrenal axis in sheep with hypothalamic-pituitary disconnection I. Effect of an audiovisual stimulus and insulininduced hypoglycemia Neuroendocrinology 48 551-560

Engler D, Pham T, Fullerton MJ, Ooi G, Funder JW and Clarke IJ (1989) Studies of the secretion of corticotropin-releasing factor and arginine vasopressin into the hypophysialportal circulation of the conscious sheep I. Effect of an audiovisual stimulus and insulin-induced hypoglycemia Neuroendocrinology 49 367-381

Ferin M (1993) Stress and the gonadal axis in the female rhesus monkey: interface between the immune and neuroendocrine systems Human Reproduction (Supplement 2) 8 147-150

Fuquay JW and Moberg GP (1983) Influence of the pituitaryadrenal axis on the induced release of luteinising hormone in rams Journal of Endocrinology 99 151-155

Hoff JD, Lasley BL, Wang CF and Yen SSC (1977) The two pools of pituitary gonadotropin: regulation during the menstrual cycle Journal of Clinical Endocrinology and Metabolism 44 302-312

Katawe N, Inaba T and Mori J (1993) Effects of progesterone and cortisol on the release of gonadotropinreleasing hormone from the perifused pituitary stalk-median eminence and on luteinising hormone release from the pituitary of cows Animal Reproduction Science 34 93100

Khalid M, Haresign W and Hunter MG (1991) Pituitary GnRH receptor dynamics during continuous infusion of a low dose of GnRH in seasonally anoestrous ewes Animal Reproduction Science 25 41-44

Li PS and Wagner WC (1983a) Effects of hyperadrenal states on luteinising hormone in cattle Biology of Reproduction 29 $11-24$

Li PS and Wagner WC (1983b) In vivo and in vitro studies on the effect of adrenocorticotropic hormone or cortisol on the pituitary response to gonadotropin releasing hormone Biology of Reproduction 29 25-37

Liptrap RM and McNally PJ (1976) Steroid concentrations in cows with corticotropin-induced cystic ovarian follicles and the effect of prostaglandin $\mathrm{F} 2 \alpha$ and indomethacin given by intrauterine injection American Journal Veterinary Research $37 \quad 369-375$

MacLusky NJ, Naftolin F and Leranth C (1988) Immunocytochemical evidence for direct synaptic connections between corticotropin-releasing factor (CRF) and gonadotropin-releasing hormone $(\mathrm{GnRH})$-containing neurons in the preoptic area of the rat Brain Research 439 391-395

Malven PV (1987) Searching for an inhibitory action of bloodborne $\beta$-endorphin on LH release Journal of Reproduction and Fertility Supplement 34 9-16

Matteri RL, Watson JG and Moberg GP (1984) Stress or acute adrenocorticotrophin treatment suppresses LHRH-induced $\mathrm{LH}$ release in the ram Journal of Reproduction and Fertility 72 385-393 
Matteri RL, Moberg GP and Watson JG (1986) Adrenocorticotrophin-induced changes in ovine pituitary gonadotrophin secretion in vitro Endocrinology 118 2091-2096

Moberg GP, Watson JG, Stoebel DP and Cook R (1981) Effect of cortisol and dexamethasone on the oestrogen-induced release of luteinising hormone in the anoestrous ewe Journal of Endocrinology 90 221-225

Mohamed FHA, Cox JE and Moonan V (1988) Studies of pituitary-adrenal-testis interaction in sheep 1 . The effects of repeated injections of adrenocorticotrophic hormone during the breeding season Theriogenology 29 849-857

Munck A, Guyre PM and Holbrook NJ (1984) Physiological functions of glucocorticoids in stress and their relation to pharmacological actions Endocrine Reviews 5 25-44

Nanda AS, Ward WR and Dobson H (1989) Effects of naloxone on the oestradiol-induced LH surge and cortisol release in transported cows Journal of Reproduction and Fertility 87 803-807

Nanda AS, Dobson H and Ward WR (1990a) Relationship between an increase in plasma cortisol during transportinduced stress and failure of oestradiol to induce a luteinising hormone surge in dairy cows Research in Veterinary Science 49 25-28

Nanda AS, Ward WR and Dobson H (1990b) Naloxone antagonises the morphine suppression of the oestradiol-induced surge of luteinising hormone in dairy cows Animal Reproduction Science 22 289-296

Naylor AM, Porter DWF and Lincoln DW (1990) Central administration of corticotrophin-releasing factor in the sheep: effects on secretion of gonadotrophins, prolactin and cortisol Journal of Endocrinology 124 117-125

Niezgoda J, Wronska D, Pierzchala K and Kahl S (1987) Lack of adaptation to repeated emotional stress evoked by isolation of sheep from the flock Journal of Veterinary Medicine A 34 734-739

Norman RL and Smith CJ (1992) Restraint inhibits luteinising hormone and testosterone secretion in intact male rhesus macaques: effects of concurrent naloxone administration Neuroendocrinology 55 405-415

Padmanabhan V, Keech C and Convey EM (1983) Cortisol inhibits and adrenocorticotropin has no effect on luteinising hormone-releasing hormone-induced release of luteinizing hormone from bovine pituitary cells in vitro Endocrinology $1121782-1787$

Parrott RF, Misson BH and de la Riva CF (1994) Differential stressor effects on the concentrations of cortisol, prolactin and catecholamines in the blood of sheep Research in Veterinary Science $\mathbf{5 6}$ 234-239

Peter AT, Simon JE, Luker CW and Bosu WTK (1990) Site of action for endotoxin-induced cortisol release in the suppression of preovulatory luteinising hormone surges Theriogenology 33 637-643
Phillips DJ and Clarke IJ (1990) Effects of the synthetic glucocorticoid, dexamethasone, on reproductive function in the ewe Journal of Endocrinology 126 289-295

Porter DWF, Lincoln DW and Naylor AM (1990) Plasma cortisol is increased during the inhibition of $\mathrm{LH}$ secretion by central LHRH in the ewe Neuroendocrinology 51 705-712

Przekop F, Wolinska-Witort E, Mateusiak K, Sadowski B and Domanski E (1984) The effect of prolonged stress on the oestrous cycles and prolactin secretion in sheep Animal Reproduction Science 7 333-342

Przekop F, Polowska J and Mateusiak K (1988) The effect of prolonged stress on the hypothalamic luteinising hormonereleasing hormone (LHRH) in the anoestrous ewe Experimental Clinical Endocrinology 91 334-340

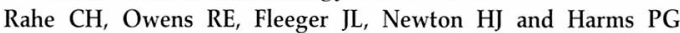
(1980) Pattern of plasma luteinising hormone in the cyclic cow Endocrinology 107, 498-503

Rasmussen DD and Malven PV (1983) Effects of confinement stress on episodic secretion of LH in ovariectomised sheep Neuroendocrinology $36 \quad 392-396$

Rivest S and Rivier C (1993) Central mechanisms and sites of action involved in the inhibitory effects of CRF and cytokines on LHRH neuronal activity Annals of the New York Academy of Sciences 697 117-141

Rivier C and Rivest S (1991) Effect of stress on the activity of the hypothalamic-pituitary-gonadal axis: peripheral and central mechanisms Biology of Reproduction 45 523-532

Smart D (1994) Adrenocorticotrophin (ACTH) $1-39$ and corticotrophin-releasing hormone $(\mathrm{CRH})$ induced changes in luteinising hormone secretion from perifused ovine pituitaries Animal Reproduction Science 37 25-34

Smart D, Singh I, Smith RF, Forhead AJ and Dobson H (1994a) The hypothalamic-pituitary-adrenal axis in post-partum ewes Animal Reproduction Science 35 223-229

Smart D, Forhead AJ, Smith RF and Dobson H (1994b) Transport stress delays the oestradiol-induced LH surge by a nonopioidergic mechanism in the early postpartum ewe Journal of Endocrinology 142 447-451

Staigmiller RB and Moor RM (1984) Effect of follicle cells on the maturation and developmental competence of ovine oocytes matured outside the follicle Gamete Research 9 221-229

Stoebel DP and Moberg GP (1982a) Repeated acute stress during the follicular phase and luteinising hormone surge of dairy heifers Journal of Dairy Science 65 92-96

Stoebel DP and Moberg GP (1982b) Effect of adrenocorticotropin and cortisol on luteinising hormone surge and estrous behavior of cows Journal of Dairy Science 65 1016-1024

Williams CL, Nishihara M, Thalabard JC, Grosser DM, Hotchkiss J and Knobil E (1990) Corticotrophin-releasing factor and gonadotrophin-releasing hormone Neuroendocrinology 52 $133-137$ 
